\title{
COMPARATIVE STUDIES BETWEEN SOME PHYSICAL AND CHEMICAL PROPERTIES OF CITRUS, CLOVER AND COTTON HONEY IN KAFR EL-SHEIKH AND BEHEIRA GOVERNORATE
}

Fatehe, A. S.

Honeybee Res. Dept., Plant Protection Res. Institute, ARC, Doki, Giza.

\begin{abstract}
Eighteen bee honey samples were collected from two different locations in Egypt, representing the following plant sources: citrus honey (six samples), clover honeys (six samples), cotton honey (six samples) Samples were collected from two different provinces represent each of them at the first geographic area Kafr El-Sheikh governorate and second are Beheira. No significant differences between treatment in all Physical, chemical properties and Suger analysis. The mineral analysis showed no significant differences among all treatments except in potassium that was significant, with lowest value (11.050) at Motobes, Kafr- El-Sheikh citrus honey and the highest value 56.1 at Abou-Elmtamir, Beheira cotton honey.
\end{abstract}

\section{INTRODUCTION}

Honey standardization is an important object to study even country in all over the world has its special honey standared, depending on the different environmental factors existing in each country. Survey of floral honey composition have established that the three major components are fructose, glucose, and water (Doner,1977) .The flora plays an important role in beehoney components and properties. Honey therapeutic varys depending on its origin. The floral source has been shown to affect largely on composition of honey. It is also possible that the components of honeys affect their antibacterial activity since honeys with lower antibacterial activities may mask the higher antibacterial activity of other honeys (Basualdo et al., 2007)

The quality of honey is mainly determined by its sensorial, chemical, physical and microbiological characteristics (Finola et al., 2007). In fact, numerous studies have been reported on the physicochemical parameters of honeys from all over the world (Azeredo et al., 2003; Finola et al., 2007; Kucuk et al., 2007; Al et al., 2009). More recently, a correlation has been established between the level of $\mathrm{H}_{2} \mathrm{O}_{2}$ and the degree of antimicrobial activity of honey. It was also suggested that $\mathrm{H}_{2} \mathrm{O}_{2}$ alone may not be sufficient to account for the antimicrobial activity (Chen et al., 2012). Phenolic compounds are among the most important groups of compounds occurring in plants, and are found to exhibit anticarcinogenic, antiinflammatory, antiatherogenic, antithrombotic, immune-modulating and analgesic activities, as then function as antioxidants (Giorgi et al., 2011).

Thus, with different compositions of active compounds in honey collected from different locations, differences in honey properties are to be expected. Diastase numbers, hydroxymethylfurfural, proline and sucrose are 
Fatehe, A. S.

usually used as indicators of the ripeness and quality of honeys (Arreaz et al., 2006).

As not all honeys are created equal in molecules terms of antimicrobial and antioxidant activity because of differences in levels of peroxide production and non-peroxide factors, which vary by floral source and processing, a comparative study has been conducted to establish the antibacterial and antioxidant potency of four varieties of honey from different botanical and geographical origins. Given the huge number of reports on the antioxidant properties of honey, the latter might be a novel antioxidant in the management of chronic diseases commonly associated with oxidative stress (Erejuwa et al., 2012).

The present study aims to investigate if the honey samples collected from different location and variable flora have an effect in physical and chemical properties of honey. and also the minerals and bacteria-inhibiting effect were studies.

\section{MATERIALS AND METHODS}

This investigation was conducted at the Sakha Agricultural Research Station and helth monestar laboratory during the period of 2011 to Identify differences in the physical and chemical properties and concentration of minerals in honey collected from different location.

\section{Collecting honey Samples :}

Eighteen honey samples were collected from two different locations in Egypt(Kafr El-Sheikh governorate and EL-Beheira governrat), representing the following plant sources: citrus honey, clover honey, cotton honey (six samples each). The samples were collected from two different provinces; Kafr El-Sheikh and second are Beheira governorate. All samples were stored in plastic containers, and kept in cool conditions $\left(-10 \mathrm{c}^{\circ}\right)$. The samples were analyzed at The Ministry of Health Labs for the following properties:

\section{Physical properties}

\section{1. water content (\%)}

Water content of tested honey samples was carried out according to the methods of Wedmore (1955), Whit et al (1962) and A.O.A.C (1995)

\subsection{Total soluble solids \% ( T. S. S. \%):.}

T.S.S.\% of honey samples was measured by using Abbe refractometer standardized at $20^{\circ} \mathrm{C}$ according to A.O.A.C (1995). This measurement may reflect the sugar content in honey

\subsection{Specific gravity:}

The specific gravity of testing samples was measured according to Wedmor (1955), and therefore, tabulated water content \% was calculated and honey grades were determined, according to White (1967). Top grade honeys (A\&B) contain not more than $18.6 \%$ water; grade $\mathrm{C}$ contains water $\%$ to $20 \%$, and grade D contains more than $20 \%$ water

\subsection{Viscosity:}

The viscosity of honey samples was measured by using a Viscometer at 29C, according to Munro (1943). 


\subsection{Colors (as optical density)}

The optical density of all samples was determined, and the color was measured by using the relation between optical density and USDA color standards as indicated by the White (1978)

\subsection{Electrical conductivity.}

\subsection{Granulation:}

Based on the method of Vorwohl (1964)

The granulation of different types of examined honey was measured according to White et al. (1962) as the percentage between glucose and fructose $(D / L)$.

\section{Chemical properties:}

\subsection{Sugars}

The concentrations of fructose $\%$, glucose $\%$, sucrose $\%$ and maltose $\%$ of honey samples were determined by High-Performance Liquid Chromatography (HPLC) according to the method of Bogdanov and Baumann (1988).

\subsection{Minerals}

The following minerals were determined in the tested samples; $\mathrm{K}$ (potassium), $\mathrm{Na}$ (sodium), Mn (manganese), $\mathrm{Cu}$ (copper), Fe (ferric), $\mathrm{Zn}$ (Zink) and $\mathrm{Pb}$ (lead) .

Determination was carried out according to Chapman and Pratt

One gram of the dried honey sample was accurately weighed and digested in a Kjeldahle flask with $10 \mathrm{ml}$. Of 3:2:1 nitric - Perchloric - sulfuric acid mixture. The contents of the flask were heated slowly to encourage smooth digestion without stirring. After complete digestion, the flask was strongly heated to remove excess nitric and perchloric acids and to reduce the volume of the solution. The solution was cooled and transferred quantitatively into a $100 \mathrm{ml}$.Volume with diagnosed water. A blank experiment was carried out by using $10 \mathrm{ml}$. of the acid mixture. The contents of $\mathrm{K}, \mathrm{Na}, \mathrm{Mn}, \mathrm{Cu}, \mathrm{Fe}, \mathrm{Zn}$ and $\mathrm{Pb}$ were determined by using an atomic absorption method, FMD3 Zeiss, according to Chapman and Pratt (1978).

\section{3. $\mathrm{PH}$ and total acidity}

$\mathrm{pH}$ and total acidity were determined according to White et al (1962)

\subsection{Hydroxy methyl furfural (HMF)}

The method of determination was carried out according to Winkler (1955)

All data were organized and programmed using a computer for statistical analysis according to "t" test.

\section{RESULTS AND DISCUSSION}

Date in the table (1) showed that no significant difference among location, as well as among crops, at all treatements 
Fatehe, A. S.

Table (1): Physical properties of clover, citrus and cotton honey

\begin{tabular}{|c|c|c|c|c|c|c|}
\hline \multirow[b]{2}{*}{ Location } & \multirow[b]{2}{*}{$\begin{array}{c}\text { Honey } \\
\text { type }\end{array}$} & \multicolumn{5}{|c|}{ Properties } \\
\hline & & Moisture & $\begin{array}{c}\text { Specific } \\
\text { Gravity }\end{array}$ & $\begin{array}{c}\text { Electric } \\
\text { conductivity } \\
\text { (EC) }\end{array}$ & $\begin{array}{l}\text { Total } \\
\text { soluble } \\
\text { solids } \\
\text { (T.S.S) }\end{array}$ & Color \\
\hline $\begin{array}{l}\text { Sakha } \\
\text { (Kafr-El-Sheikh) }\end{array}$ & \multirow[t]{2}{*}{ Clover } & $19.000^{\mathrm{a}}$ & $1.410^{\mathrm{a}}$ & $0.017^{a}$ & $81.000^{\mathrm{a}}$ & $0.312^{\mathrm{a}}$ \\
\hline $\begin{array}{l}\text { Abou-ELmatamir, } \\
\text { (Beheira) }\end{array}$ & & $21.000^{\mathrm{a}}$ & $1.395^{\mathrm{a}}$ & $0.011^{a}$ & $79.000^{a}$ & $0.358^{\mathrm{a}}$ \\
\hline $\begin{array}{l}\text { Motobes, } \\
\text { (Kafr El-Sheikh) }\end{array}$ & \multirow[t]{2}{*}{ Citrus } & $20.000^{a}$ & $1.407^{\mathrm{a}}$ & $0.013^{\mathrm{a}}$ & $80.500^{a}$ & $0.162^{\mathrm{a}}$ \\
\hline $\begin{array}{l}\text { Abou-ELmatamir, } \\
\text { (Beheira) }\end{array}$ & & $19.500^{\mathrm{a}}$ & $1.403^{\mathrm{a}}$ & $0.010^{a}$ & $80.000^{a}$ & $0.212^{\mathrm{a}}$ \\
\hline $\begin{array}{l}\text { Sakha } \\
\text { (Kafr El-Sheikh) }\end{array}$ & \multirow[t]{2}{*}{ Cotton } & $22.000^{\mathrm{a}}$ & $1.395^{\mathrm{a}}$ & $0.051^{a}$ & $78.000^{a}$ & $0.525^{a}$ \\
\hline $\begin{array}{l}\text { Abou-ELmatamir, } \\
\text { (Beheira) }\end{array}$ & & $22.000^{a}$ & $1.395^{\mathrm{a}}$ & $0.046^{a}$ & $78.000^{a}$ & $0.459^{\mathrm{a}}$ \\
\hline
\end{tabular}

For each column, means followed by the same letter did not differ significantly at the $5 \%$ level

Date in the table (2) showed that no significant difference among location, as well as among crops, at all treatement

Table (2): Chemical properties of clover, citrus and cotton honey

\begin{tabular}{|c|c|c|c|c|c|c|}
\hline \multirow[b]{2}{*}{ Location } & \multirow[b]{2}{*}{$\begin{array}{l}\text { Honey } \\
\text { type }\end{array}$} & \multicolumn{5}{|c|}{ Properties } \\
\hline & & PH & $\begin{array}{l}\text { Free } \\
\text { acidity }\end{array}$ & Lacton & $\begin{array}{c}\text { Total } \\
\text { acidity }\end{array}$ & $\begin{array}{c}\text { Hydroxy } \\
\text { Methylfurfural } \\
\text { (H.M.F) }\end{array}$ \\
\hline $\begin{array}{l}\text { Sakha } \\
\text { (Kafr- El-Sheikh) }\end{array}$ & \multirow[t]{2}{*}{ Clover } & 3.65 & $48.00^{a}$ & $5.00^{a}$ & $53.00^{a}$ & $3.84^{\mathrm{a}}$ \\
\hline $\begin{array}{l}\text { Abou-ELmatamir, } \\
\text { (Beheira) }\end{array}$ & & 3.40 & $38.00^{a}$ & $12.50^{\mathrm{a}}$ & $50.50^{a}$ & $0.00^{\mathrm{a}}$ \\
\hline $\begin{array}{l}\text { Motobes, } \\
\text { (Kafr El-Sheikh) }\end{array}$ & \multirow[t]{2}{*}{ Citrus } & 3.73 & $28^{a}$ & $1.0^{\mathrm{a}}$ & $29^{a}$ & $9.6^{a}$ \\
\hline $\begin{array}{l}\text { Abou-ELmatamir, } \\
\text { (Beheira) }\end{array}$ & & 3.62 & $43^{a}$ & $7.5^{\mathrm{a}}$ & $50.5^{a}$ & $3.84^{a}$ \\
\hline $\begin{array}{l}\text { Sakha } \\
\text { (Kafr El-Sheikh) }\end{array}$ & \multirow[t]{2}{*}{ Cotton } & 3.780 & $68.000^{a}$ & $7.500^{a}$ & $75.500^{a}$ & $13.440^{a}$ \\
\hline $\begin{array}{l}\text { Abou-ELmatamir, } \\
\text { (Beheira) }\end{array}$ & & 3.700 & $55.500^{\mathrm{a}}$ & $1.000^{\mathrm{a}}$ & $56.500^{a}$ & $1.920^{\mathrm{a}}$ \\
\hline
\end{tabular}

For each column, means followed by the same letter did not differ significantly at the $5 \%$ level

Date in the table (3) showed that no significant difference among location, as well as among crops, at all treatements. 
Table (3): Suger analysis of clover, citrus and cotton honey

\begin{tabular}{|c|c|c|c|c|c|}
\hline Location & $\begin{array}{l}\text { Honey } \\
\text { type }\end{array}$ & $\begin{array}{c}\text { Fructose } \\
(\%)\end{array}$ & $\begin{array}{c}\text { Glucose } \\
(\%)\end{array}$ & $\begin{array}{c}\text { Sucrose } \\
(\%)\end{array}$ & $\begin{array}{c}\text { Maltose } \\
(\%)\end{array}$ \\
\hline Sakha, Kafr- El-Sheikh & \multirow[b]{2}{*}{ Clover } & $39.0^{\mathrm{a}}$ & $31.5^{\mathrm{a}}$ & $1.2^{\mathrm{a}}$ & $3.25^{\mathrm{a}}$ \\
\hline $\begin{array}{l}\text { Abou-Elmtamir, } \\
\text { (Beheira) }\end{array}$ & & $39.0^{\mathrm{a}}$ & $29.9^{a}$ & $3.1^{\mathrm{a}}$ & $4.9^{\mathrm{a}}$ \\
\hline \begin{tabular}{|lll}
$\begin{array}{l}\text { Motopes } \\
\text { Sheikh) }\end{array}$ & (Kafr & El \\
\end{tabular} & \multirow[t]{2}{*}{ Citrus } & $40.0^{a}$ & $31.0^{\mathrm{a}}$ & $1.6^{\mathrm{a}}$ & $3.5^{\mathrm{a}}$ \\
\hline Abou-Elmtamir, Beheira & & $39.9^{a}$ & $30.2^{a}$ & $1.5^{\mathrm{a}}$ & $4.2^{\mathrm{a}}$ \\
\hline Sakha, (Kafr- El-Sheikh) & \multirow[b]{2}{*}{ Cotton } & $28.0^{a}$ & $42.0^{a}$ & $0.57^{\mathrm{a}}$ & $1.95^{\mathrm{a}}$ \\
\hline $\begin{array}{l}\text { Abou-ELmtamir, } \\
\text { (Beheira) }\end{array}$ & & $32.0^{\mathrm{a}}$ & $33.8^{\mathrm{a}}$ & $0.46^{\mathrm{a}}$ & $4.7^{\mathrm{a}}$ \\
\hline
\end{tabular}

For each column, means followed by the same letter did not differ significantly at the $5 \%$ level

Date in the table (4) revealed no significant differences between meaning in manganese with lowest value (1.9) at Abou-Elmtamir, Beheira citrus honey, highest value (2.03) at the Sakha research station, Kafr- ElSheikh cotton honey, ferric with lowest value 1.9 in Abou-Elmtamir, Beheira cotton honey, highest value (1.68) at the Sakha research station,Kafr- ElSheikh cotton honey. Zink exhibited the lowest value (0.129) at Sakha research station, Kafr- El-Sheikh cotton honey, highest value 1.68 in in Abou-Elmtamir, Beheira clover honey. Sodium with lowest value (15.48) at Motobes,Kafr- El-Sheikh citrus honey, highest value (59.34) at Sakha research station, Kafr- El-Sheikh cotton honey and Copper displayed the lowest value (0.590) at Motobes, Kafr- El-Sheikh citrus honey, highest value (2.68) at Abou-Elmtamir, Beheira citrus honey. However The potassium values were significant higher at Abou-Elmtamir (Beheira) cotton and citrus honey than at in Sakha research station (Kafr- El-Sheikh) cotton and (Kafr ElSheikh) Motobes citrus honey.

Table (4): Minerals content of honey

\begin{tabular}{|l|c|c|c|c|c|c|c|}
\hline \multicolumn{1}{|c|}{ Location } & $\begin{array}{c}\text { Honey } \\
\text { type }\end{array}$ & $\begin{array}{c}\text { MN } \\
\text { Ppm }\end{array}$ & $\begin{array}{c}\text { FE } \\
\text { Ppm }\end{array}$ & $\begin{array}{c}\text { ZN } \\
\text { Ppm }\end{array}$ & $\begin{array}{c}\text { K } \\
\text { Ppm }\end{array}$ & $\begin{array}{c}\text { NA } \\
\text { Ppm }\end{array}$ & $\begin{array}{c}\text { CU } \\
\text { Ppm }\end{array}$ \\
\hline $\begin{array}{l}\text { Sakha } \\
\text { (Kafr- El-Sheikh) }\end{array}$ & Clover & $2.100^{\mathrm{a}}$ & $1.450^{\mathrm{a}}$ & $0.105^{\mathrm{a}}$ & $22.100^{\mathrm{a}}$ & $21.500 \mathrm{a}$ & $0.920^{\mathrm{a}}$ \\
\cline { 1 - 6 } $\begin{array}{l}\text { Abou-ELmatamir, } \\
\text { (Beheira) }\end{array}$ & $2.020^{\mathrm{a}}$ & $1.420^{\mathrm{a}}$ & $0.329^{\mathrm{a}}$ & $21.250^{\mathrm{a}}$ & $20.64^{\mathrm{a}}$ & $1.070^{\mathrm{a}}$ \\
\hline $\begin{array}{l}\text { Motobes, } \\
\text { (Kafr El-Sheikh) }\end{array}$ & \multirow{2}{*}{ Citrus } & $1.970^{\mathrm{a}}$ & $0.93^{\mathrm{a}}$ & $0.043^{\mathrm{a}}$ & $11.050^{\mathrm{a}}$ & $15.48^{\mathrm{a}}$ & $0.590^{\mathrm{a}}$ \\
\cline { 1 - 6 } $\begin{array}{l}\text { Abou-ELmatamir, } \\
\text { (Beheira) }\end{array}$ & $1.900^{\mathrm{a}}$ & $1.21^{\mathrm{a}}$ & $0.168^{\mathrm{a}}$ & $31.450^{\mathrm{b}}$ & $21.50^{\mathrm{a}}$ & $2.680^{\mathrm{a}}$ \\
\hline $\begin{array}{l}\text { Sakha } \\
\text { (Kafr El-Sheikh) }\end{array}$ & \multirow{2}{*}{ Cotton } & $2.030^{\mathrm{a}}$ & $1.680^{\mathrm{a}}$ & $0.129^{\mathrm{a}}$ & $26.350^{\mathrm{a}}$ & $59.34^{\mathrm{a}}$ & $2.000^{\mathrm{a}}$ \\
\cline { 1 - 6 } $\begin{array}{l}\text { Abou-ELmatamir, } \\
\text { (Beheira) }\end{array}$ & $1.970^{\mathrm{a}}$ & $0.930^{\mathrm{a}}$ & $0.297^{\mathrm{a}}$ & $56.100^{\mathrm{b}}$ & $40.42^{\mathrm{a}}$ & $1.240^{\mathrm{a}}$ \\
\hline
\end{tabular}

For each column, means followed by the same letter did not differ significantly at the $5 \%$ level 
Fatehe, A. S.

From the obtained results, it could be suggested that in the physical properties of clover, citrus and cotton honey did not differ significantly in the two areas in all tretements . In chemical properties of clover, citrus and cotton honey no significant different between all treatment in the two areas. However, no significant different between mains in Sugars and minerals except in potassium in the two geographic areas. These differences may be due to the change in climatic factors, differentiation of farmer fertilirization practices and the different between the two geographic areas. Many authors discussed the physical, chemical, sugar analysis and Mineral content properties of the honey and found that, The quality of honey is mainly determined by its sensorial, chemical, physical and microbiological characteristics. The criteria for ensuring quality honey have been specified by the EC Directive 2001/110 (Kirk, et al 1992). EC is one of the most important factors for determining the physical characteristics of honey (Serrano et al 2004). The major criteria are moisture content, electrical conductivity, ash content, reducing and non-reducing sugars, free acidity, diastase activity and Hydroxy Methylfurfural (H.M.F) content (AL, et al 2009). The $\mathrm{pH}$ of honey samples is important during the extraction process because it affects the texture of honey as well as its stability and shelf life (Terrab, et al 2002).

Ajlouni and Sujirapinyokul (2010) reported low Hydroxy Methylfurfural (H.M.F) concentrations of two unprocessed Australian honey samples, gray box and Banksia (1.35 and $1.12 \mathrm{mg} / \mathrm{kg}$, respectively). The highest limit set for total sugar content by the European community directive (Council Directive of the European Union, 2002)

\section{REFERENCES}

Ajlouni, S.; and Sujirapinyokul, P. (2010):Hydroxymethylfurfuraldehyde and amylase contents in Australian honey. Food Chem., 119, 1000-1005.

Al, M.L. - Daniel, D. - Moise, A. - Bois, O. - Laslo, L. BogdanovO, S. (2009): Physicochemical and bioactive properties of different floral origin honeys from Romania. Food Chemistry, 112. 863-867.

A.O.A.C. (1995): Association of Official Analytical Chemists, $16^{\text {th }} \mathrm{Ed}$., Washington, DC, USA.

Arreaz-Roman, D.; Gomez-Caravaca, A.M.; (2006): Gomez-Romero, M.; Segura-Carretero, A.; Fernandez-Gutierrez, A. Identification of phenolic compounds in rosemary honey using solid-phase extraction by capillary electrophoresis-electrospray ionization-mass spectrometry. $\mathrm{J}$. Pharm. Biomed. Anal., 41, 1648-1656.

Basualdo, C. - Sgroy, V. - Finola, M.S. - Marioli, J.M. (2007). Comparison of the antibacterial activity of honey from different provinces against bacteria usually isolated from skin wounds. Veterinary Microbiology, 124: 375-381.

Bogdanov, S and E. Baumann (1988): Determination of honey sugars with HPLC. Mitteilungen. Aus. Dem. Gebiete. Der. LebensMitteluntersuchung. Undo Hygiene. 79: 198-206.

Ajlouni, S.; Sujirapinyokul, P. (2010): Hydroxymethylfurfuraldehyde and amylase contents in Australian honey. Food Chem., 119: 1000-1005. 
Chapman, H.D. and P.F. Pratt (1978). Methods ofanalysis for soils, plants, and water. Univ. of Calif., Publ. no. 4034. p. 70-72.

Chen, C.; Campbell, L.T.; Blair, S.E.; Carter, D.A (2012): The effect of standard heat and filtration processing procedures on antimicrobial activity and hydrogen peroxide levels in honey. Front. Microbiol., 3: 17.

Council Directive of the European Union (2002). Council directive 2001/110/ec of 20 December 2001 relating to honey. Off. J. Eur. Communities, 47-52.

Domer, L.W. (1977): The sugers of honey - Areview, J. Sci. food Agric., 28,443-456

Duncan, D. B. (1955). Multiple range and multiple $\mathrm{F}$ test. Biometrics, 11: 142.

Erejuwa, O.O.; Sulaiman, S.A.; Ab Wahab, M.S. Honey (2012): A novel antioxidant. Molecules, 17: 4400-4423.

Finola, M.S. - Lasagna, M.C. - Marioli, J.M., (2007). Microbiological and chemical characterization of honeys from central Argentina. In Food Chemistry, 100: 1649-1653.

Giorgi, A.; Madeo, M.; Baumgartner, J.; Lozzia, G.C (2011): The relationships between phenolic content, pollen diversity, physicochemical information and radical scavenging activity in honey. Molecules, 16: 336-347.

Kirk, R.; Sawyer, R. Herbs and spices, salt. Composition and Analysis of Foods, 9th Ed.; (1991):Longman Scientific and Technical: Harlow, UK,; 391-429.

Munro, J. A., (1943): The viscosity and thixotrophy of honey. J. Econ, Ent., 36 (5): 769-777.

Persano, O.L.; Piazza, M.G.; Sabatini, A.G.; (1995):Accorti, M. Characterization of unifloral honeys. Apidologie, 26: 453-465.

Serrano, S.; Villarejo, M.; Espejo, R.; Jodral, M (2004): Chemical and physical parameters of Andalusian honey: Classification of citrus and eucalyptus honeys by discriminant analysis. Food Chem., 87: 619-625.

Terrab, A.; Dí ez, M.J.; Heredia, F.J. (2002): Characterization of Moroccan unifloral honeys by their physicochemical characteristics. Food Chem., 79: 373-379.

Vorwohl, G. (1964): Relationships between the electrical conductivity of honeys and their floral origin. Ann. Abeille,7: 301-309.

Wedmore, E.B. (1955): The accurate determination of the water content of honeys. 1- Introduction and results. Bee World, 36 (11): 197-202.

White, J.W.; MN.L. Riethof; M.H. Subers and I. Kushnir (1962): Composition of American honeys. U.S. Dept. Agr. Tech. Bull., 1261: 124.

White, J.W. (1967): Measuring in honey quality a rational approach. Amr. Bee J, 107 (10): 374- 375.

White, J.W (1978): Honey.Adv.Fd.Res.24:187.

Winkler , o. (1955):Beitrag Zum Nachweis und zur Bestimmung Von oxmethylufural in Honig und kunsthonig.z. Lebensmittelunters. U. Forsch. 102(3)161-167. 
Fatehe, A. S.

مقارنة بين بعض الخصائص الطبيعية والكيميائية لعسل المـوالح والبرسيم والقطن من محافظة كفر الثيخ والبحيرة أشرف شريف فتحي

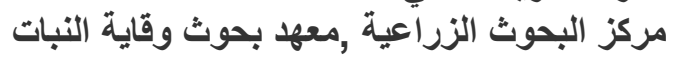

جمعت ثماني عشر عينة من العسل من موقعين مختلفين و التي تمثنل المصـادر

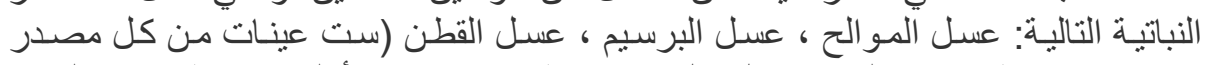

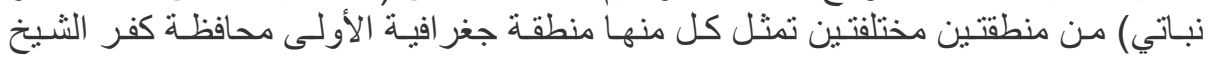

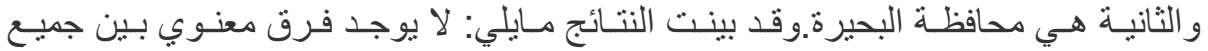

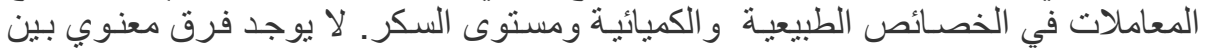

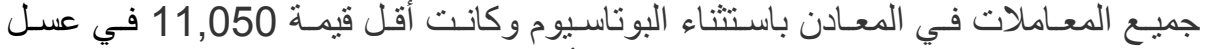

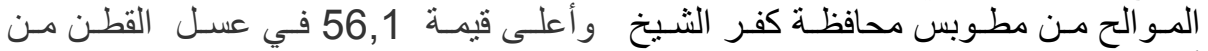

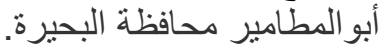

كلية الزراعة - جامعة المنصورة قام بتحكيم البحث

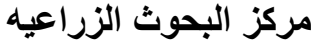

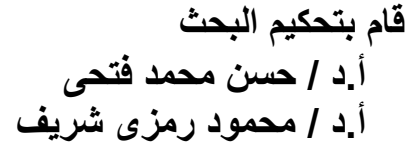

